\title{
Using SNPs to find my roots
}

AUTHOR:

Brenda Wingfield $^{\top}$

\section{AFFILIATION:}

${ }^{1}$ Faculty of Natural and

Agricultural Sciences, University

of Pretoria, Pretoria, South Africa

\section{CORRESPONDENCE TO:}

Brenda Wingfield

\section{EMAIL:}

brenda.wingfield@fabi.up.ac.za

\section{POSTAL ADDRESS:}

Faculty of Natural and Agricultural Sciences, University of Pretoria, Pretoria 0002 , South Africa

\section{KEYWORDS:}

genetics; ancestry; genome; single nucleotide polymorphism; lineage

\section{HOW TO CITE:}

Wingfield B. Using SNPs to find my roots. S Afr J Sci. 2014;110(1/2), Art. \#a0046, 1 page. http://dx.doi. org/10.1590/sajs.2014/a0046
South Africa has been a true democracy for almost 20 years. There have been many positive developments in this time; some (including those relating to science) seem almost miraculous when one considers for instance some of the consequences of the Arab Spring. Despite our two decades of freedom from apartheid, we sadly remain a substantially racially divided nation. As a scientist with a strong interest in genetics, my own racial heritage has always been of interest to me. Although sequencing one's own genome remains inordinately expensive for the average person, determining one's single nucleotide polymorphism (SNP) genotype has become relatively inexpensive. And it is against this background that I now have confirmation of who my own ancestors were.

It is almost fashionable in South Africa to be able to claim a southern African ancestor. My DNA analysis shows that while I can claim to be $1 \%$ African, there is nothing to suggest that any of my ancestors ever lived in southern Africa. This finding must clearly be viewed against the backdrop of the fact that humans originated in Africa. My ancestors obviously left Africa a very long time ago! I can, however, report that I share $2.9 \%$ of my genome with Neanderthals, for whatever that is worth. My current theory - and I am sticking to it - is that Neanderthals were blonde!

I grew up with the knowledge that my great-great-grandfather, 23 generations back, was Robert the Bruce. For those not raised on European history, he was King of Scots in 1306. Much time has passed since he was king and I do not have any claims on the Scottish throne nor is there any evidence of any family treasure to which I might have rights. However, my father was very proudly Scottish. My mother can trace her English ancestors back to the Tudors and her mother was Irish. It is thus not at all surprising that my DNA profile is 50-70\% English or Celtic and that overall I am 98\% European with a very small Northern African and Asian influence.

My mitochondrial genome is also one of the European lineages. In his popular book The Seven Daughters of Eve, Bryan Sykes ${ }^{1}$ named the originator of my mtDNA haplogroup Jasmine. I obviously come from a very long line of European women and I have passed my mitochondrial genome on to my children.

The story regarding my 'roots' is exactly what I expected. But it was interesting (somewhat reassuring) to have it confirmed and to understand some of the other aspects of my gene pool. It was also fascinating to learn how much we know already as a result of Genome Wide Association Genetics. Based on my SNP genotype, I am predicted to be blonde and to have blue eyes. The fact that this reflects my phenotype exactly is both reassuring and also shows how much one can tell from just a million SNPS.

Testing for genetic diseases based on SNP linkage has become a component of the commercially available tests that the medical profession is already using. It is thus important that we come to understand more about genetics and our own genomes. Yet, there are also some complex consequences to having access to all these data. For example, in the South African context, the availability of these data may force a re-evaluation of our various racial classifications. In parts of the USA, the 'one drop rule' has been applied to race classification - any mixed race ancestry determines one's race. I would suggest that having one's genomic data available vividly illustrates how pointless these various classification systems really are. We are all probably a bit of a mixture - some, such as myself, a bit more 'European', while others are finding unexpected 'roots' to celebrate.

The poet Langston Hughes ${ }^{2}$ wrote in his 1940 memoir

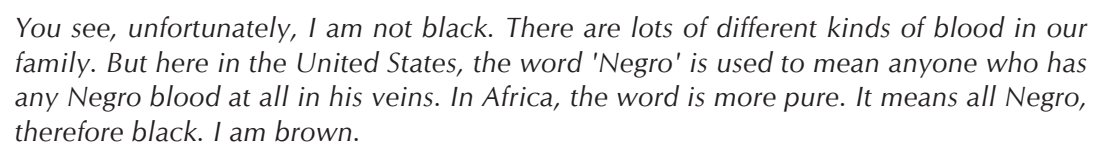

A colleague of mine who has a mixed-race son once told me that, in her homeland, her child is 'neither White nor Black but rather just beautiful'. The data of our genomes will ultimately be available to us all. And hopefully they will emphasise the fact that the human race is something truly beautiful to behold.

\section{References}

1. Sykes B. The seven daughters of Eve. London: Bantam Press; 2001.

2. Hughes L. The big sea, an autobiography. New York: Knopf; 1940. 